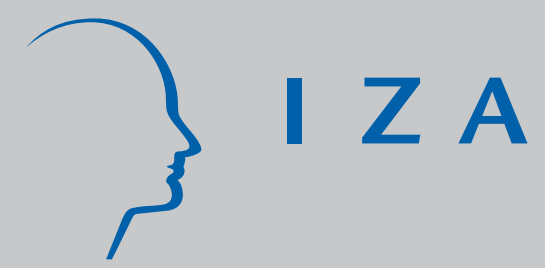

IZA DP No. 8162

Economic Growth and Political Integration: Estimating the Benefits from Membership in the European Union Using the Synthetic Counterfactuals Method

Nauro F. Campos

Fabrizio Coricelli

Luigi Moretti

April 2014 


\title{
Economic Growth and Political Integration: Estimating the Benefits from Membership in the European Union Using the Synthetic Counterfactuals Method
}

\author{
Nauro F. Campos \\ Brunel University and IZA \\ Fabrizio Coricelli \\ Paris School of Economics and CEPR \\ Luigi Moretti \\ University of Padova \\ Discussion Paper No. 8162 \\ April 2014 \\ IZA \\ P.O. Box 7240 \\ 53072 Bonn \\ Germany \\ Phone: +49-228-3894-0 \\ Fax: +49-228-3894-180 \\ E-mail: iza@iza.org
}

\begin{abstract}
Any opinions expressed here are those of the author(s) and not those of IZA. Research published in this series may include views on policy, but the institute itself takes no institutional policy positions. The IZA research network is committed to the IZA Guiding Principles of Research Integrity.

The Institute for the Study of Labor (IZA) in Bonn is a local and virtual international research center and a place of communication between science, politics and business. IZA is an independent nonprofit organization supported by Deutsche Post Foundation. The center is associated with the University of Bonn and offers a stimulating research environment through its international network, workshops and conferences, data service, project support, research visits and doctoral program. IZA engages in (i) original and internationally competitive research in all fields of labor economics, (ii) development of policy concepts, and (iii) dissemination of research results and concepts to the interested public.
\end{abstract}

IZA Discussion Papers often represent preliminary work and are circulated to encourage discussion. Citation of such a paper should account for its provisional character. A revised version may be available directly from the author. 


\section{ABSTRACT \\ Economic Growth and Political Integration: Estimating the Benefits from Membership in the European Union Using the Synthetic Counterfactuals Method ${ }^{*}$}

This paper presents new estimates of the economic benefits from economic and political integration. Using the synthetic counterfactuals method, we estimate how GDP per capita and labour productivity would have behaved for the countries that joined the European Union (EU) in the 1973, 1980s, 1995 and 2004 enlargements, if those countries had not joined the EU. We find large positive effects from EU membership but these differ across countries and over time (they are only negative for Greece). We calculate that without deep economic and political integration, per capita incomes would have been, on average, approximately 12 percent lower.

JEL Classification: $\quad$ C33, F15, F43, O52

Keywords: economic growth, European Union, synthetic counterfactuals

Corresponding author:

Nauro F. Campos

Department of Economics

Brunel University

Uxbridge UB8 3PH

United Kingdom

E-mail: nauro.campos@brunel.ac.uk

\footnotetext{
* We would like to thank Thomas Bassetti, Laszlo Bruszt, Youssef Cassis, Efrem Castelnuovo, Luca Corazzini, Saul Estrin, Davide Fiaschi, Lorenzo Forni, Nikolaos Georgantzís, Seppo Honkapohja, likka Korhonen, Tommaso Nannicini, Jeffrey Nugent, Lorenzo Rocco, Paola Valbonesi and seminar participants at the University College London, University of Padova, University of Pisa, Central Bank of Finland, European Economic Association 2013 Conference (Gothenburg), ISNIE 2013 Conference (Florence), French Economic Association 2013 Meetings (Aix en Provence), Italian Economic Association 2013 Conference (Bologna), ADRES-DC 2014 (Paris-Dauphine), and Royal Economic Society 2014 Meetings (Manchester) for valuable comments on previous versions. On-line appendix is available at https://sites.google.com/site/morettilg/eugrowth. The usual disclaimer applies.
} 


\section{Introduction}

The process of economic integration in Europe is now more than half a century old. The Second World War provided impetus and, even if from the outset this process was driven much by politics, considerations about economic benefits have always been paramount. Integration has since the 1950s deepened and broadened, with slowdowns but without major reversals. In the wake of the Great Recession and of the Euro Crisis, the vigorous debate about the economic benefits from membership in the European Union ${ }^{1}$ (EU) may hardly have come as a surprise. What is surprising, however, is how much economic research still lags in quantifying these benefits. This paper argues that the evidence remains disappointingly thin and, trying to address this gap, presents improved estimates of the monetary benefits countries derive from being members of the EU. It reports substantial and positive increases in per capita GDP after EU membership for all countries that joined in the 1973, 1980s, 1995 and 2004 enlargements, with the exception of Greece.

There are at least two important reasons or motivations for this exercise, one theoretical and the other empirical. The theoretical literature delivers contradictory implications with respect to the relationship between political and economic integration. On the one hand, Alesina et al. (2000) argue that economic and political integration are substitutes and shore up their explanation for this negative relationship by stressing heterogeneous preferences and fractionalisation. On the other hand, Martin et al. (2012) argue that economic and political integration are complements. Supporting this positive relationship, this strand of literature offers a sharp distinction between shallow and deep integration, with the latter combining economic and political integration. "Economic integration, when not accompanied by political integration, can lead to less innovation and slower growth as firms respond to increased competition in the economic market by focusing more on rent-seeking activity. When economic integration is accompanied by

\footnotetext{
${ }^{1}$ We use the term European Union (or EU for short) for convenience throughout, that is, even when referring to what was then called the European Economic Community (up to 1967) or the European Communities (until 1992).
} 
political integration, innovation and growth will be stronger and welfare higher" (Brou and Ruta, 2011, p. 1143).

The empirical motivation for this paper refers to the dearth of evidence. There is a disappointingly small literature offering econometric estimates of the monetary benefits from EU membership. To be more precise, there are few studies that answer questions such "what would be the level of per capita income in a given country had it not joined the EU?" Many believe, incorrectly, that this literature is vast because of the many excellent works on the benefits from trade liberalization, from the Single Market, and from the Euro. ${ }^{2}$ Yet studies on the benefits of membership itself are few. ${ }^{3}$ Moreover, the majority of these (few) papers warn about the fragility of their own estimates. Henrekson et al. estimate the benefits from membership to be about 0.6 to 0.8 percent per year but note that such estimates are "not completely robust" (1997, p. 1551). Badinger (2005) estimates that "GDP per capita of the EU would be approximately one-fifth lower today if no integration had taken place since 1950" but cautions that these are "not completely robust" (p. 50.) Crespo et al. (2008) find large growth effects from EU membership, but warn that country heterogeneity remains a severe concern.

There are of course difficulties in assessing the benefits from European Integration because of endogeneity, omitted variables, measurement errors and causality concerns. The latter are arguably the most severe as the construction of credible counterfactual scenarios have so far proved difficult. Counterfactuals are important to identify causal relationships. But, as Boldrin and Canova admonish, "historical counterfactuals (what would have happened if transfers had not taken place?) are hard to construct" (2001, p.7).

2 See, among others, Baldwin (1989), Baldwin and Seghezza (1996), and Frankel (2010), respectively.

${ }^{3}$ Badinger and Breuss (2011) and Sapir (2011) survey the literature and offer two somewhat different reasons for this paucity. Badinger and Breuss note that "Generally it is easier to conduct ex ante studies on economic integration than to analyse the outcome ex post. This is also documented by the much larger number of ex ante studies. Some of the rare ex post studies, in particular those on the Single Market, are somewhat disillusioning. The expected pro- competitive effects and the implied growth bonus from the Single Market appear to have not been fully realised so far. To some extent this also applies to EMU" (p. 308). Sapir (2011) notes that while the literature on the static benefits of integration is vast, that on the dynamic benefits is scarce. 
Similarly, Boltho and Eichengreen caution that "imagining the counterfactual is no easy task" (2008, p.13). This paper is an attempt to construct robust counterfactuals in terms of the growth and productivity effects from European Integration, by using the synthetic counterfactuals method (or "synthetic control methods for causal inference in comparative case studies") pioneered by Abadie and Gardeazabal (2003). ${ }^{4}$ We present new evidence for output and productivity effects at country level, and for various EU enlargements (1973, the 1980s, 1995 and 2004).

The main research questions are as follows: Are there tangible economic benefits from European Integration or are these benefits mostly political? Do EU members grow faster than non-EU members? Can these growth and productivity differentials be causally associated with EU membership? Or more specifically, what would have been the current levels of per capita GDP and labour productivity in these countries had they not become full-fledged EU members?

In order to construct counterfactuals, we take advantage of the "simplicity" (or binarity) of membership in the EU, as well as of the fact that the EU has experienced four major increases in membership ("enlargements") in the last four decades (1970s, 1980s, 1990s and 2000s). However, there are three important issues to bear in mind: (a) the complexity of integration, (b) its timing and (c) the matter of inter-temporal comparisons. The first refers to the fact that although EU membership is ultimately binary (a country is or is not a full-fledged EU member), there is a continuum of degrees of economic integration, which cannot be captured by a dummy variable. There are many areas over which economies integrate (finance, goods, services, technology, policies, etc.) and it is plausible that the process of integration varies across such areas as well as over time. The second difficulty refers to timing, as EU membership is announced in advance. ${ }^{5}$

\footnotetext{
${ }^{4}$ See Imbens and Wooldridge (2009) for a discussion of the synthetic counterfactuals methodology and how it compares with other recent program evaluation methods.

5 This anticipation effect is not uncommon. For instance, the effects of the Euro on bilateral trade are detected already for 1998, which is the year before the adoption of the common currency (see Frankel, 2010, pp.177-179 for a discussion).
} 
Anticipation effects may reduce the relevance of the official date of EU accession as "treatment". A third important difficulty is due to the fact that enlargements were spread over time in each of the last four decades (1970s, 1980s, 1990s and 2000s). Therefore, the set of incumbent countries differs for each enlargement, which makes it difficult to compare results across enlargements. And, obviously, the more recent is the enlargement, the shorter is the post-accession period. ${ }^{6}$

Although the three issues highlighted above caution the interpretation of the results of the econometric analysis, the way we implemented the synthethic counterfactual method bias downwards the effects of integration we estimate. In this method it would be legitimate to use, for each of the new EU members, different specifications, different donor pools and different accession dates. We chose to use the same specification, donor pool and treatment dates for each enlargement. In this sense, we believe the estimates reported below are conservative estimates of the growth and productivity effects of EU accession.

The main results of the paper are as follows. The estimated growth and productivity effects from deep integration (i.e., the economic and political benefits from EU membership) are positive and substantial. Yet, there is considerable heterogeneity across countries. Surprisingly, estimates indicate that only one country experienced smaller GDP or productivity growth rates after EU accession (that is, Greece). Our estimates suggest that per capita European incomes in the absence of the economic and political integration process would have been on average 12 per cent lower today, with substantial variations across countries, enlargements as well as over time (discussed in detail below). These estimates are within the range of estimates previously obtained in the literature, which point to a minimum of 5 percent (Boltho and Eichengreen, 2008) gains in per capita income from EU accession, to a maximum of 20 percent gains (Badinger, 2005).

These estimates are robust to various measures of GDP and productivity growth, to

6 It should also be taken into consideration that the "readiness criteria" has changed between the 1973 and 2004 enlargements. 
whether one focuses on the dynamic or on average effects of EU membership, to changes in the donor pool of countries (ranging from the whole world to a small set of countries), and to substantial changes in the covariates used in the estimation.

The paper also makes a methodological contribution. It uses a difference-indifferences approach to address one of the main drawbacks of the synthetic counterfactual method, namely the difficulty of estimating confidence intervals for the counterfactual effects (and hence of making statements about the significance of these estimates). ${ }^{7}$

The paper is organized as follows. Section 2 briefly discusses previous attempts at estimating the growth and productivity effects from EU membership. Section 3 presents the synthetic counterfactual methodology. Section 4 introduces our baseline results. Section 5 presents and discusses various sensitivity checks including evidence on anticipation effects, difference-in-differences estimates and considerations about the introduction of the Euro. Section 6 concludes.

\section{Growth and Productivity Effects from European Integration}

Despite the destruction caused by the Second World War, the subsequent economic recovery was swift and, already by the early 1950s, most European countries had per capita GDP that were equal or above their pre-war levels (Crafts and Toniolo, 2008). This recovery was followed by a period known as the Golden Age of European growth (Temin 2002). As shown in Table 1, between 1950 and 1973 Western and Eastern Europe grew at unprecedented rates (Eichengreen, 2007). Economic and political integration are prominent among the various explanations, which emphasized that the rapid and comprehensive policy of trade liberalization generated growth payoffs in the context of both the EU- 6 and EFTA. 8

\footnotetext{
${ }^{7}$ Acemoglu et al. (2013) suggests a different approach to address this drawback, based on bootstrap methods.

8 EFTA (European Free Trade Association) was established in 1960. The founding members were Denmark, United Kingdom, Portugal, Austria, Sweden, Norway and Switzerland (only the last two remain as members).
} 
[Insert Table 1 about here]

The process of European Integration progressed over time both in depth and in extent. The deepening of trade liberalization in the 1960s was followed by the first EU enlargement in 1973 (with the accession of the UK, Ireland and Denmark). The 1980s see further increases in EU membership (Greece in 1981 and Spain and Portugal in 1986), which were followed by deepening in terms of the Single Market policy. By its turn, this was followed by another enlargement (Austria, Finland and Sweden in 1995) and another deepening with the introduction of the common currency. This was followed by the largest of the enlargements in 2004 (and then Bulgaria and Romania in 2007 and Croatia in 2014).

The deepening and broadening of European Integration have generated substantial growth and productivity payoffs to the point that many scholars attach exceptionality to Europe, in being the only region in which one can find evidence of unconditional beta and sigma convergences (Eichengreen, 2007). Per capita incomes in Europe did catch-up with the U.S. at least until 1995, when the gap seems to have started to widen again. ${ }^{9}$

The early literature conjectured that the effects of integration on growth worked through the effects of integration on trade.10 Baldwin and Seghezza (1996) provide an excellent survey and conclude that European integration has helped to accelerate European growth because trade liberalization boosted investment in physical capital in Europe. ${ }^{11}$ A seminal contribution in the endogenous growth tradition is the work by RiveraBatiz and Romer (1991). ${ }^{12}$ They argue that economic integration for countries with similar incomes per capita leads to long-run growth effects if it accelerates technological

\footnotetext{
9 Three important considerations have to be kept in mind: (a) these gaps behave very differently when considering per capita GDP or GDP per hour worked (Gordon 2011); (b) there is substantial cross-country variation within Europe, and (c) the Great Recession has had substantial impact on more recent trends.

10 For a critical view see Slaughter (2001).

11 An important issue with this earlier literature is that the evidence it generates focuses on the effects of international trade on growth and often assumes that all the increase in the trade is driven purely by intra-European integration efforts (for instance downplaying globalization).

12 Jones and Romer (2010) propose an updated Kaldor list of stylized facts that stresses the importance of integration: "Fact 1: Increases in the extent of the market. Increased flows of goods, ideas, finance, and people - via globalization, as well as urbanization-have increased the extent of the market for all workers and consumers" (p. 229).
} 
innovation (mostly through larger R\&D activities leading to new ideas). Such effects can also be achieved through larger trade in goods if the production of ideas does not need the stock of knowledge as an input (in the so-called lab-equipment model). In short, the effects of economic integration on growth depend on specific channels leading to possible longterm benefits either through larger flows of trade of goods or flows of ideas (Ventura, 2005). Furthermore, the growth dividend depends as well on the degree of similarity in terms of incomes per capita of the countries involved in integration. Finally, also note that models of economic integration generally abstracts from the role of institutional characteristics of the countries involved. In view of the theoretical difficulties in deriving clear-cut effects of integration on growth (which includes a lack of debate on the type of integration, i.e., deep versus shallow), empirical analysis remains paramount.

There is a large economic history literature on European Integration. ${ }^{13}$ This is closely related to (and broadly supported by) a rich growth accounting literature (e.g. O’Mahony and Timmer, 2009). Furthermore, there are several studies that associate integration (for instance, in terms of Structural Funds) with economic growth at the regional level (see Becker et al., 2010). In addition, there have been various econometric attempts to estimate the growth and productivity effects of EU membership, among them Henrekson et al. (1997), Badinger (2005), and Kutan and Yigit (2007). ${ }^{14}$

These (few) papers all warn about the fragility of their own estimates. Henrekson et al. estimate the benefits from membership to be about 0.6 to 0.8 percent per year but note that such estimates are "not completely robust" (1997, p. 1551). Badinger (2005) estimates that "GDP per capita of the EU would be approximately one-fifth lower today if no integration had taken place since 1950" but cautions that these are "not completely robust" (p. 50.) Crespo et al. (2008) find large growth effects from EU membership, but warn that country heterogeneity remains a severe concern.

\footnotetext{
${ }^{13}$ See among others Boltho and Eichengreen (2008) and Crafts and Toniolo (2008).

${ }^{14}$ For a survey, see Badinger and Breuss (2010).
} 
In summary, there is an important literature that has attempted to directly address the issue of the growth dividends from EU membership. Most of it uses panel data econometrics and information on the 1980s and 1990s enlargements to infer the size of these growth payoffs and to assess whether or not they can be said to be permanent or temporary. We echo Eichengreen and Boltho's (2008) concern that one main difficulty in these analyses is the satisfactory identification of a benchmark, of a baseline country for comparison or a fully specified counterfactual. In our view, the literature so far has not satisfactorily addressed this difficulty and hence our goal here is to generate a set of transparent, rigorous and credible counterfactual scenarios that can support statements about causality from economic and political integration, on the one hand, and economic and productivity payoffs on the other.

\section{Synthetic counterfactuals: Methodological and data issues}

This paper empirically investigates whether membership in the EU has generated payoffs in terms of per capita income. In order to do that, we use a recently developed methodology, "synthetic control methods for causal inference in comparative case studies" or, in short, synthetic counterfactuals, which was developed by Abadie and Gardeazabal (2003) and Abadie et al. (2010, 2012). ${ }^{15}$ Here we estimate what would have been the levels of per capita GDP in a given country if such country had not become a full-fledged member of the European Union.

The synthetic control method estimates the effect of a given intervention (in this case, EU membership) by comparing the evolution of an aggregate outcome variable (per capita GDP) for a country affected by the intervention vis-à-vis the evolution of the same aggregate outcome for a synthetic control group. The synthetic control method answers questions such as "what would have been the level of per capita GDP in Finland after 1995

\footnotetext{
${ }_{15}$ Imbens and Wooldridge (2009) discuss the synthetic counterfactuals method among other recent developments in the econometrics of program evaluation.
} 
if Finland had not become a full-fledged member of the EU as it did in 1995?" Below, we answer such questions for all countries that became EU members in the 1973, 1980s, 1995 and for all but two of those in the 2004 enlargement (we exclude Malta and Cyprus).

The synthetic counterfactual method focuses on the construction of the "synthetic control group," or in the words of Imbens and Wooldridge, of an "artificial control group" (2009, p. 72). It does so by searching for a weighted combination of other units (control countries), which are chosen to match as close as possible the country affected by the intervention, before the intervention or treatment occurs, for a set of predictors of the outcome variable. The evolution of the outcome for the synthetic control group is an estimate of the counterfactual. It shows what the behaviour of the outcome variable (here per capita GDP) would have been for the affected country if the intervention had (not) happened in the same way as in the control group. ${ }^{16}$

More formally, the estimation of the average effect on the treated unit is represented by:

$$
\tau_{i t}=Y_{i t}^{I}-Y_{i t}^{C}
$$

where $Y_{i t}^{I}$ is the outcome of a treated unit $i$ at time $t$, while $Y_{i t}^{C}$ is country $i$ 's outcome at time $t$ had it not been subjected to treatment (in this case, had it not become a full-fledged member of the European Union). We observe the outcome of the treated country $Y_{i t}^{I}$ after the treatment (with $t \geq T_{0}$ ), but do not observe what the outcome of this country would be in the absence of treatment (i.e., the counterfactual, $Y_{i t}^{C}$, for $t \geq T_{0}$ ). Abadie et al. (2010) propose a method to identify and estimate the dynamic treatment effect $\left(\tau_{i t}\right)$ considering the potential outcome for the country's $i \in I$ under the following general model:

$$
Y_{i t}^{I}=\delta_{t}+\alpha_{i t} D_{i t}+v_{i t}
$$

\footnotetext{
16 Abadie and Gardeazabal (2003) investigate "what would have been the levels of per capita GDP in the Basque country in Spain if it had not experienced terrorism?" Abadie et al. (2010) present two further examples: "what would have been cigarette consumption in California without Proposition 99?" and "what would have been the per capita GDP of West Germany without reunification?" (2012). Other recent papers using this method include Campos and Kinoshita (2010) on foreign direct investment, Lee (2011) on inflation targeting, Billmeier and Nannicini (2013) on trade liberalization, and Acemoglu et al. (2014) on political connections.
} 


$$
\begin{aligned}
& Y_{i t}^{C}=\delta_{t}+v_{i t} \\
& v_{i t}=\theta_{t} Z_{i}+\lambda_{t} \omega_{i}+\varepsilon_{i t}
\end{aligned}
$$

where $Z_{i}$ is a vector of independent variables at country level (either time-invariant or time-variant); $\theta_{t}$ is a vector of parameters; $\lambda_{t}$ is an unknown common factor; $\omega_{i}$ is a country specific unobservable term; $\varepsilon_{i t}$ is a zero-mean transitory shock, and $\alpha_{i t} D_{i t}=\tau_{i t}$, where $D_{i t}$ is dummy variable which takes value 1 when the country $i \in I$ is exposed to the treatment, and zero otherwise.

Suppose we observe the outcome $Y_{i t}$ and a set of determinants $Z_{i t}$ of the outcome for $N+1$ countries, where $i=1$ is the treated country and $i=2, \ldots, N+1$ are the (untreated) control countries, for each period $t \in[1, T]$, with the intervention on country $i=$ 1 beginning at time $T_{0} \in(1, T)$. In order to construct a counterfactual, a weighted average of $Y_{i t}$ (with $i=2, \ldots, N+1$, and $t<T_{0}$ ) is estimated to approximate $Y_{1 t}$ (for $t<T_{0}$ ), taking into account the covariates $Z$. The set of weights is $W=\left(w_{2}, \ldots, w_{n+1}\right)$, with $w_{i} \geq 0$ (for $i=2, \ldots, N+1)$ and $\sum_{i=2}^{N+1} w_{i}=1$, thus pre-treatment:

$$
\sum_{i=2}^{N+1} w_{i} Y_{i t}=Y_{1 t}
$$

and

$$
\sum_{i=2}^{N+1} w_{i} Z_{i}=Z_{1}
$$

For the choice of the optimal set of weights $W^{*}$, consider, in matrix notation, $X_{1}$ the $(k \times 1)$ vector of the treated country 1 characteristics in the pre-treatment period; $X_{C}$ the $(k \times N)$ vector of the same characteristics for the control or "donor" countries; and, $V$ a $(k \times k)$ symmetric and positive semi definite matrix, which measures the relative importance of the characteristics included in $X$. The optimal vector of weights $W^{*}$ solves the following minimization problem:

$$
\begin{gathered}
\min \left(X_{1}-X_{C} W\right)^{\prime} V\left(X_{1}-X_{C} W\right) \\
\text { s.t. } w_{i} \geq 0(\text { for } i=2, \ldots, N+1) \text { and } \sum_{i=2}^{N+1} w_{i}=1
\end{gathered}
$$

That is, $W^{*}$ is selected to minimize the pre-treatment distance between the vector of the treated country characteristics and the vector of the potential synthetic control 
characteristics. $W^{*}$ is chosen to minimize the mean squared error of pre-treatment outcomes. $^{17}$

The synthetic counterfactual is constructed using the optimal weight $W^{*}$ so that $\sum_{i=2}^{N+1} w_{i}^{*} Y_{i t}$ (with $t \geq T_{0}$ ) is an approximate estimation of $Y_{1 t}^{C}$. The treatment effects are estimated as:

$$
\hat{\tau}_{i t}=Y_{1 t}-\sum_{i=2}^{N+1} w_{i}^{*} Y_{i t} \quad \text { for all } t \geq T_{0} .
$$

The path of the weighted average of untreated countries (i.e. the synthetic control) hence matches or mimics the path of the treated country in the absence of treatment. The accuracy of the estimation depends on the pre-treatment distance of the synthetic control with respect to the treated country. All else equal, a longer pre-treatment period allows for a more accurate synthetic control.

The synthetic counterfactuals method entail two identification assumptions: (1) the choice of the pre-treatment characteristics should include variables that can approximate the path of the treated country, but should not include variables that anticipate the effects of the intervention; and (2) the countries used to obtain the synthetic control (those in the "donor pool") must not be affected by the treatment.

The first assumption implies that the treatment effects are not anticipated, that is, that they start in full at the date assigned for the treatment. Here, the absence of anticipation effects means that the growth effects of EU membership are to be observed only after each candidate country effectively becomes a full-fledged member. If agents form expectations that anticipate these effects (for example, if foreign investors behave as if a given country is a EU member before it actually joins the EU) the synthetic counterfactual method will generate a lower-bound estimate of the true effect because part of it occurs before the start of the treatment (EU accession in this case). ${ }^{18}$

\footnotetext{
17 In this paper we use the distance metric available in the STATA econometric software (the relevant command is synth). See Abadie et al. (2010) for further details.

18 In the synthetic counterfactuals below, we do find interesting evidence of anticipation. It is particularly noticeable in the 2004 enlargement (but not as much in the 1973, 1980s and 1995 enlargements). We discuss these issues in detail below.
} 
The second assumption requires that countries we selected to generate the synthetic control group should not be affected by the treatment. Although this assumption clearly holds when one defines the treatment as "full-fledged EU membership," it must be recognized that integration is a continuum and not a dummy variable. ${ }^{19}$ Having in the donor pool some countries that are integrated with the EU but not full-fledged members should also help to generate lower-bound or conservative estimates of the true effect of membership, assuming that the level of per capita GDP in these "not formally integrated" countries would have been lower without "partial integration."20

Our choice of pre-treatment characteristics is based upon the specification used by Abadie and Gardeazabal (2003) but is more parsimonious. It includes the investment share of per capita GDP, population growth and initial income (all from Penn World Tables 7.0, PPP converted at 2005 constant prices), share of agriculture in value added, share of industry in value added, secondary gross school enrolment (percentage) and tertiary gross school enrolment (all from the World Bank's World Development Indicators). ${ }^{21}$

In a way, the synthetic control approach represents an extension of the differencesin-differences framework by allowing the effects on unobserved variables on the outcome to vary over time. This is similar to the "policy-experiment approach" discussed among others by Henry (2007). Moreover, it “allow(s) researchers to perform inferential exercises about the effects of the event or intervention of interest that are valid regardless of the number of available comparison units, the number of available time periods, and whether aggregate or individual data are used for the analysis" (Abadie et al., 2010). This method addresses endogeneity and omitted variable concerns but has as its main drawback the fact that it

19 See Dorrucci et al. (2004) and Friedrich et al. (2013) for continuous indexes of economic integration in Europe, and König and Ohr (2012) for a review of recent efforts.

${ }^{20}$ Baldwin notes that "Nations such as Switzerland and Norway resisted joining but have instead signed agreements that oblige them to implement most EU laws in exchange for equal access to the EU market. They have, however, no formal input in the lawmaking process. Most nations in Europe looked at this 'regulation without representation' and decided they would have more control inside the EU despite Qualified Majority Voting" (2008 p. 128).

${ }^{21}$ Note that, following Nannicini and Billmeier (2013), we use these covariates only when they are available for at least one year in the pre-treatment period. 
"does not allow assessing the significance of the results using standard (large-sample) inferential techniques, because the number of observations in the control pool and the number of periods covered by the sample are usually quite small in comparative case studies" (Billmeier and Nannicini, 2013, p. 987). Here we implement a simple yet novel solution to this drawback, namely using the difference-in-differences estimator for the actual vis-à-vis the synthetic series (more details below). This shores up statements about the statistical significance of the effect of EU membership on per capita GDP levels on average, before and after.

\section{Synthetic counterfactuals: Baseline results}

The baseline synthetic counterfactual results using the methodology and data discussed above are presented in Figures 1 to 2 . There are two series plotted in each. The series represented by the continuous line shows the actual per capita GDP of the country in question, while the series represented by a dashed line shows the estimated synthetic counterfactual. The question guiding each one of these exercises is: What would have been the GDP per capita levels of the country in question if it had not become an EU member? The synthetic counterfactuals are estimated for each country in all four EU enlargements, namely for Denmark, Ireland and the UK in 1973, Greece, Portugal and Spain in the 1980s Southern enlargement, for Austria, Finland and Sweden in the 1995 Northern enlargement and for the Eastern European countries in the 2004 enlargement. ${ }^{22}$ The results are presented for a donor pool of countries originally used by Bower and Turrini (2010). The reported results are robust to large changes in donor pool (from the whole world to a selected number of countries), suggesting this specific donor pool is not critical. ${ }^{23}$

22 We have excluded from our analysis Cyprus and Malta because their relative small size (and the difficulties this generate to find good matching experiences) and Bulgaria and Romania because the period post-EU membership is precariously short.

${ }^{23}$ We have experimented with various "country donor pools" and the results below are robust to the most dramatic changes, that is (see Table A.5 in Appendix), to using the whole world,a few selected EU geographical neighbors, or countries that experienced "low volatility" of growth rates during the periods of analyses (to ensure that results are not driven by shocks on the donor countries). The 
[Insert Figures 1 to 2 here]

Let us consider, as an example, the case of Spain. Figure 1 shows the evolution of real per capita GDP in Spain between 1970 and 2008. Spain became a full-fledged member of the EU in 1986 and hence this is the year the treatment was administered (as shown by the vertical dotted line). The weights for the countries in the donor pool are reported in the Appendix. The set of optimal weights for "synthetic Spain" are 0.358 to New Zealand, 0.373 to Brazil and 0.268 to Canada (and, for example, 0\% for Albania or Japan). The graph shows the actual Spanish per capita GDP levels between 1970 and 2008 (continuous line) with the dotted line plotting the same values for the synthetic counterfactual, that is, for a synthetic Spain that did not become a full-fledge EU member in 1986. The results suggest that per capita GDP in Spain would be considerably lower today had it not joined the EU in 1986. Indeed, they show it would have been lower in every single year since 1986 . The actual and the synthetic Spain series are reasonably close and move together before 1986, while they start to diverge in or around 1986. This indicates there was little anticipation or delay of the effects from EU membership. Furthermore, the gap between actual and synthetic Spain seems to be constant, suggesting that the benefits from EU membership in this case are more likely to be permanent than temporary. The results for Portugal are similar, with sizeable, and permanent for per capita GDP, benefits from EU membership. The main country donors to the construction of per capita GDP series of "synthetic Portugal" are Philippines and Chile (weights of 0.239 and 0.237 respectively). Overall, these results show substantial increases in per capita GDP for all countries that joined the EU in the 1980s and in 2004, with Greece as the only exception.

results reported in this paper are for an intermediary donor pool originally from Bower and Turrini (2010) which contains the following non-EU countries: Argentina, Australia, Belarus, Brazil, Canada, Chile, China, Hong Kong, Colombia, Croatia, Egypt, Indonesia, Iceland, Israel, Japan, Korea, Morocco, Mexico, Macedonia, Malaysia, New Zealand, Philippines, Russia, Singapore, Switzerland, Thailand, Tunisia, Turkey, Ukraine, and Uruguay. 
The results for the remaining country that joined the EU in the 1980s (Greece in 1981) deserve attention. The estimates show that Greek per capita GDP would have been higher if Greece had not become a full-fledged EU member in 1981. However, notice that, on the positive side, the gap shrinks over time, suggesting that the strength of this statement weakens during the latter part of the time window (after 1995). But does this imply Greece would be better off leaving the EU as quickly as possible? This is surely not the point we are making. From 1981 to 1995, growth rates in the EU were relatively higher and Greece experienced divergence (Vamvakidis, 2003). The opening up of the uncompetitive domestic industry may have been too sudden. ${ }^{24}$ Yet entry into the economic and monetary union represents a turnaround, with growth rates faster than in the EU for 1996-2008, driven by shipping, tourism and the financial sector. Mind the latter is one of the few sectors in which structural reforms were implemented (Mitsopoulos and Pelagidis, 2012). Until the Crisis, integration delayed a broad range of structural reforms in Greece. Signs are that this is now slowly changing (Fernández-Villaverde et al., 2013).

In the Summer of 1961, Denmark, Ireland and the UK submitted official applications for accession to the European Communities. ${ }^{25}$ When France vetoed the UK application, the other candidates withdrew (Bache et al., 2011). Applications were resubmitted and, in 1969, accepted with accession in 1973. The results suggest that per capita GDP would be considerably lower in these countries had they not joined the EU in 1973. The actual and the synthetic series are reasonably close before 1973 (more so for labour productivity than per capita GDP), while they since diverge, indicating that there was little anticipation of the effects from EU membership. ${ }^{26}$ In addition, the difference

${ }^{24}$ In 1976, the Council of Ministers extraordinarily rejected the European Commission's view which was against opening accession negotiations with Greece and in favour of delaying entry until Greek producers were deemed able to compete in the Common Market.

${ }_{25}$ Recall that these three countries were founding members of the European Free Trade Area (EFTA). EFTA was successful at increasing trade among its members, but not as successful as the European Community. Also note that at the time of entry, Denmark was the richest of the three, with Ireland's per capita GDP comparable to (slightly higher than) the UK's. In terms of GDP size, the UK was and remains the (much) larger economy.

26 This is generally true for all countries here, with the exception of Finland's per capita GDP but 
between actual and synthetic does not diminish, suggesting that the benefits from membership seem more likely to be permanent than temporary. The dynamics of these benefits is noteworthy. For example, the benefits from EU membership for the UK (although substantial throughout) may have slowed down in later years while for Ireland they seem to have accelerated instead. This suggests that the UK benefited more from the Single Market while Ireland did benefit mostly from the common currency. ${ }^{27}$

In 1995, Austria, Finland and Sweden joined the EU. The results for Austria and Finland suggest that EU membership generated permanent dividends in terms of per capita GDP. In the case of Finland, the pre-treatment matching is good especially considering the depth of the economic crisis the country went through in the early 1990s. The results for Sweden show a more nuanced picture in that there seem to have been less effect from EU membership in terms of per capita GDP. Overall, the estimated payoffs from EU membership for Sweden, and to a lesser extent Austria and Finland, seem small compared to those in the 1973 enlargement. One interpretation is that when these latter three countries joined the EU they already had a relatively high level of per capita income. ${ }^{28} \mathrm{We}$ believe this interpretation may be incorrect and this is in part due to the similar payoffs from 1973 and 1986 enlargements An alternative explanation is the possibility that the 1973 countries designed, implemented and benefited from the Single Market (1986-1992) and, especially in the case of Ireland, from the common currency (as well as from attendant advances in financial integration). The main impediment for the 1995 countries to join was political (the Cold War) and their benefits from EU membership seem mostly in terms of labour productivity (and less in terms of per capita GDP). Future research should

this is mostly due to the Finnish banking crisis of 1991-1993.

${ }^{27}$ In spite of the sharp contraction of output that Ireland suffered during the Great Recession, its GDP per capita (in PPP) remains in 2014 ten per cent higher than that of the UK (according to IMF WEO data).

28 The "per capita income gap at entry" is the percentage difference between the per capita income average of existing members and that of candidate countries, in USD PPP, for the official accession year. We calculate that candidate countries in 1973 had on average $96 \%$ of the per capita income of existing members, in the 1980s this was $63 \%$, in 1995 this was $103 \%$, while in 2004 it was $45 \%$. Interestingly, the actual figure for Greece in 1981 and Portugal and Spain in 1986 is the basically the same (63\%) and that for East Germany in 1990 is surprisingly close (64\%). 
investigate fully the reasons for the relatively worse performance of the 1995 class. One line of inquiry we deem worth pursuing stresses institutions. If the bulk of the benefits the EU provide is to encourage institutional change than one would expect the potential gains that membership could generate in Austria, Finland and Sweden in 1995 to be indeed smaller than those in Denmark, Ireland and UK in 1973.

Let us focus on the results for the Eastern European countries that joined the EU in 2004. The picture is somewhat mixed in this case, as benefits from EU membership starting appear few years before the actual accession date: that is, there seems to have been anticipation of the effect. With this caveat, which we will discuss in detail in section 5, overall these results show satisfactory pre-treatment matching. However, for some countries the benefits are quite clear, while for others they are difficult to identify. Countries in the first group include Estonia, Latvia, Lithuania, while countries in the latter group are basically the Czech Republic, Poland, Slovakia, Slovenia and Hungary. Notice that, for instance, in the case of Poland we report negative payoffs from membership but these are because in this version of this paper we decided to use a more parsimonious specification throughout that, inter alia, excludes trade openness. Once we account for the power of anticipation effects (details in next section), these benefits from EU membership are found to be positive. To put it differently, trade openness seems to be a crucial mechanism through which countries benefit from EU membership, and this is particularly strong for the 2004 enlargement.

In summary, the synthetic counterfactual methodology seems effective in identifying the dividends in terms of per capita GDP from EU membership. Further, they indicate that these dividends are positive and that they often tend to be substantial and long lasting in spite of heterogeneity across countries (we discuss differences in the magnitude of these effects in the next section). Specifically, per capita GDP or productivity 
levels ${ }^{29}$ significantly increase with EU membership in Denmark, Ireland, United Kingdom, Portugal, Spain, Austria, Finland, Estonia, Latvia and Lithuania. The effects are smaller but still positive, for Sweden, Czech Republic, Slovakia, and Slovenia. Finally, and surprisingly, the evidence supports the view that only one country (Greece) experienced lower per capita GDP or productivity compared to its counterfactual after EU accession.

\section{Anticipation effects, difference-in-differences and understanding EU benefits}

The objective of this section is to further probe the baseline results above. We discuss three extensions: (a) "placebos in time" in order to assess anticipation effects; (b) difference-indifferences estimates for the comparison between the actual and the synthetic series to make conventional statistical significance statements; and (c) analysis of the potential determinants of the cross-country variation of the benefits from EU accession. ${ }^{30}$

Firstly, we carry out a robustness test to account for the possibility of "anticipation effects," in particular in the context of the 2004 Eastern enlargement. This is because the 2004 Eastern enlargement might have been different in various aspects (see Elvert and Kaiser, 2004, and Bache et al 2011). The Eastern enlargement was the largest in terms of entrants but it also required substantial institutional change and this partly explains why it took longer. ${ }^{31}$ In order to evaluate the importance of these anticipation effects we reestimate the synthetic counterfactuals but instead of using the official accession date (in this case, 2004) we specify 1998 as the treatment year. As the Figure 3 shows, for per

\footnotetext{
29 See Figure A.1, A.2 and A.3 in Appendix for the synthetic counterfactual results on labor productivity.

${ }^{30}$ In the Appendix, we report placebo tests on donor countries. The results from placebo tests broadly support our main conclusions above and are reported in Figures A.4 to A.7. Such placebo tests compare the effects on the treated country with those obtained by subjecting the donor countries to the same treatment. In most of the cases, the effect on the EU countries is greater than the effects on the donor countries (however notice that in some donor countries the pre-treatment mismatch is very large). An extension we do not report in this version refers to the use of regional data for the 1995 enlargement.

${ }^{31}$ Kutan and Yigit (2007) present econometric evidence supporting the view that the 1980s and 1990s enlargements did not suffer from severe anticipation effects. They estimate structural breaks in GDP and productivity series and report that they occur substantially close to the "official" accession dates.
} 
capita GDP anticipation effects seem to matter as there is evidence that the positive growth dividends from EU membership are larger once these are taken into account (with the exception of the Czech and Slovak Republics).

[Insert Figure 3 about here]

Second, we address one well-known drawback of the synthetic control method, namely the fact that there is no accepted way of carrying out standard hypotheses tests and, consequently, there is a limited amount one can say about the confidence that can be attached to the estimates. Therefore, we estimate difference-in-differences models for the actual and synthetic series of each country so as to be able to make statements about the level of statistical significance of their differential. ${ }^{32}$ In order to do that one incurs a cost, namely that the statistical tests are necessarily run for differences before and after, that is, for average values before and after treatment. Perhaps statistical significance will be harder to attain for those countries in which these gaps are not constant over the posttreatment window. This is why these results may be somewhat conservative. Table 2 reports these tests, first for each country and then for each of the four enlargements, and for both GDP and labour productivity series.

[Insert Table 2 about here]

The results in Table 2 confirm, for average effects, that the economic benefits from EU membership estimated above are substantial. That is, the differences between the synthetic counterfactual series and the actual series are statistically significantly different from zero. This is the case for Denmark, United Kingdom and Ireland (both for GDP per capita and for labour productivity), Spain (for GDP), Portugal (both for GDP and for labour

${ }^{32}$ See Bertrand et al. (2004) for a critique of the difference-in-differences approach. 
productivity), Greece (note the average effect is negative), and Austria (both for GDP and for labour productivity). There are no significant average differences in the cases of Sweden and Finland. Considering the 1998-anticipation effects on the 2004 enlargement, differences are also not statistically significant for the Czech Republic, Poland, Slovakia and Slovenia (for GDP per capita). This contrasts to the cases of Estonia, Hungary, Latvia, and Lithuania in which the differences (pay-offs) are significant both for GDP per capita and for labour productivity and Slovenia for labour productivity.

In summary, the difference-in-differences estimates provide support to the synthetic counterfactuals results, especially in the case of the 1970s and 1980s enlargements. For the countries of the 1995 enlargement and for Eastern countries, these results are somewhat weaker, which may be due to the fact that these averages are for shorter posttreatment periods (compared to the previous enlargements).

Difference-in-differences allows us to generate additional results for each of the four enlargements individually (by pooling Greece into the 1986 enlargement). These are presented in the bottom panel of Table 2. The growth dividends from EU membership for the countries that became EU members in 1973 are positive and statistically significant at conventional levels. For the 1980s enlargement, statistical significance is observed for per capita GDP when we exclude Greece. For the 1995 enlargement, the average labour productivity effects are statistically significant, while the same can be said for the per capita GDP and productivity effects in the 2004 enlargement.

The difference-in-differences results in Table 2 complement the synthetic counterfactual results in the sense that they allow us to state that the average differences in GDP or productivity are statistically different after EU membership. However, what about the magnitude of these effects? Table 3 reports a simple calculation of the differences between before and after EU accession (that is, the differences between their actual and their levels predicted by the synthetic counterfactuals), for each country, in percentage terms (in the case of GDP per capita) and in percentage points (in terms of per 
capita GDP growth). It reports three versions of each of these: the average difference for the whole post-accession period, the average difference for the first ten and for the first five years after accession to the EU.

[Insert Table 3 about here]

Focusing on per capita GDP levels (columns 1 to 3 in Table 3), one can see that there is little evidence that the difference (the effect of EU accession) decreases over time, after each enlargement. Column 1 shows that the 1970s enlargement has the highest growth dividends, while the 1986 enlargement (Spain and Portugal) and the Eastern enlargement have higher growth dividends than those from the 1995 enlargement. However, the 1970s, 1980s (excluding Greece), and the Eastern enlargement (considering anticipation effects) have similar payoffs over the ten years after accession. These are the preferred estimates and they suggest that incomes would have been around 12 per cent lower today if European Integration had not happened. For the countries that joined EU in the 1980s and for the Eastern enlargement (accounting for the anticipation effect) there is not a large difference between the results for the whole post accession period compared to its first ten years. ${ }^{33}$ Ireland is an exception in that the benefits from membership accrue later (one can speculate that structural funds and increased capital mobility may be the main reasons). If one focuses on the more comparable "first ten years after accession," one can identify Latvia, Lithuania and Estonia as the countries that have benefited the most and, again, Greece as the one that has benefited the least (to a lesser extent, the others are Sweden, Finland and the Czech and Slovak Republics). As an overall grand average of these effects, we calculate that these countries' per capita incomes would be about 12 per cent lower today if they had not joined the EU at the time they did. These conclusions are

${ }^{33}$ Note that for the countries in the 2004 enlargements, the results for the whole post accession period (1998-2008) coincide with the results for the first 10 years (1998-2008). Yet, the results remain very similar if we focus on the first 5 -years instead. 
broadly similar when focusing on growth rates. On average, without European integration growth rates would have been 1.2 percentage points lower over the period and the one country that clearly stands out is again Latvia, for which the benefits from being an EU member amount to additional four percentage points in its GDP growth rate.

One final extension focuses on trying to understand the reasons behind these benefits. Why do some countries benefit so much while others benefit little? Are there potentially confounding effects from the introduction of the common currency, the Euro, and the extensive preparations that preceded it, on the growth payoffs from EU membership? In addition to its importance in policy terms, this is a crucial research topic. For researchers, it is important to understand the variation across countries and over time in terms of the dividends from EU membership (these pay-offs are proxied here by the difference between their actual levels and those predicted by the synthetic counterfactuals). In a recent study, Friedrich et al. (2013) examine a range of potential factors and focus on the relative roles of institutional quality, financial development, trade integration, financial globalization, and political integration, and conclude by favouring the latter. ${ }^{34}$ The intuition for each of these potential reasons serves our case well. Countries that have a higher level of financial development are expected to be better able to exploit and distribute the benefits of integration, although this is often a complex relationship that may depend on the level of development achieved by domestic political institutions (Campos and Coricelli, 2012). By the same token, this holds for those countries that are better integrated internationally (the latter would involve not only deeper but also different types of linkages or mechanisms as for example, foreign direct investment and cross-border banking). In the current set-up, we expect countries with higher levels of international financial integration to show larger differences between actual levels and

\footnotetext{
${ }^{34}$ Note that their context is different in that they examine why Emerging Europe are the only countries with robust growth effects from financial integration.
} 
synthetic counterfactual levels, thus larger growth pay-offs from European Union membership.

Table 4 presents panel OLS estimates from a set of regressions in which the dependent variable is the percentage difference between the actual levels of per capita GDP and those estimated from the synthetic counterfactuals, or in other words, the growth dividends or pay-offs we estimate from EU membership. These regressions account for inertia ("lagged gap") and evaluate different potential determinants: trade openness, international financial integration, and adoption of the common currency (a dummy variable for the adoption of the Euro). We also take into account the potential role of economic and political institutions. Two aspects of economic institutions are captured by measures of labor market flexibility (EPL, employment protection legislation) and economic regulation (ECTR, competition regulation in utilities industries). ${ }^{35}$ The two measures of political institutions are a general measure of democracy (from Polity IV) and an index of political constraints on the executive (POLCON). ${ }^{36}$ All specifications include the number of years of EU membership as well as country and year fixed effects.

[Insert Table 4 about here]

The overall results in Table 4 suggest that the three main factors that help understand the variations of benefits from EU membership across countries and over time are trade openness, financial integration and the adoption of the Euro. These factors are closely associated with the magnitude of the overall, average, pay-off from membership in the EU. It should be clear from this exercise that we are not assuming a causal relationship in this case, just highlighting an important association. With this in mind, the

\footnotetext{
${ }^{35}$ ETCR is the measure constructed by the OECD (2011) summarizing indicators of regulation in energy, transport and communications. It actually reflects the breadth and stringency of regulatory provisions in seven sectors: telecoms, electricity, gas, post, rail, air passenger transport, and road. 36 POLCON is described in detail in Henisz (2000) and the source for the democracy variable is the Polity IV dataset.
} 
coefficient for Euro membership suggest that countries that (later on) adopted the Euro, have on average approximately 2 percentage point larger pay-off from EU membership (recall the average payoff is approximately $12 \%$ ). In other words, everything else constant, countries that have adopted the Euro have differences between actual and synthetic levels of per capita GDP that are approximately 2 percentage points bigger on average than for those countries that have not yet adopted the Euro. Similar statements can be made with respect to both trade openness and financial integration. ${ }^{37}$ Our emphasis is that these factors seem to have statistically large and economically meaningful roles in explaining the cross-country variation of the pay-off from EU membership.

A second important set of results refers to employment protection legislation and utilities regulation which are usually considered as important aspects of economic institutions. As it can be seen, the effects of employment protection legislation are ambiguous as it is not clear whether more rigid labour markets are associated with larger or smaller benefits from EU membership. This is a topic of great academic and policy interest and further research is needed to better understand this relationship. On the other hand, the results for the stringency of utilities regulation (ECTR) are somewhat stronger and suggestive that countries in which the policy framework has converged to that in the EU seem to benefit more fully from EU membership. It is important to note that the source of these two variables is the OECD and data is available exclusively for OECD members during the period of analysis. The fact that various countries that joined the EU in 2004 are not members of the OECD explains the discrepancy between the number of observations of the first two columns and the remainder of the Table. This is why we attach little weight to the ELP and ECTR results in column 6 other than our interest in checking for possible non-linearities and to assess whether the fullest specification would affect the results for what we consider the three key factors (namely,

\footnotetext{
${ }^{37}$ Note that taken together the single and squared term the effect of how financially integrated is the country into the world economy is on average positive.
} 
trade openness, financial integration and the Euro) and we find that this does not seem to be the case.

Table 4 also presents results for measures of political institutions. As it can be seen, none of these coefficients are statistically significant at conventional levels (except for democracy, Polity 2, in the full specification, column 6 but this may be unduly capturing the effects of the smaller sample size). Perhaps this is because of two related factors, one is that most of the institutional catch-up may take place before EU accession and, second, that there is little variation in terms of the levels of development of political institutions among EU members (and so this should not be a factor explaining cross-country variation). Nevertheless, we believe future research would do well in extending the set of political institutions and investigating further the pre and post accession dynamics of these various institutions and how they affect differently the pace and magnitude of the payoffs we estimate.

\section{Conclusions}

The objective of this paper is to provide a novel and more satisfactory answer to the important question of whether one can identify significant and substantial payoffs from "deep integration" (combining economic and political aspects and using EU membership as a case study) in terms of higher per capita GDP and higher labor productivity. The main finding is that there seems to be strong evidence on positive pay-offs from EU membership, despite considerable heterogeneity across countries. More specifically, focusing on the 1973, 1980s, 1995 and 2004 enlargements, we find that per capita GDP and labor productivity increase with EU membership in Denmark, Ireland, United Kingdom, Portugal, Spain, Austria, Estonia, Hungary, Latvia, Slovenia and Lithuania. The effects tend to be smaller, albeit still mostly positive, for Finland, Sweden, Poland, Czech Republic and Slovakia. Finally, and surprisingly, the evidence shows that only one country (Greece) after EU accession experienced lower per capita GDP and labour productivity than its 
counterfactual. This highlights not just the disappointing growth performance in Greece for the first 15 years after accession (that is, 1981-1996), but also the fact that its relative performance was below par: during this period, the gap between Greek and the EU average GDP has increased. Indeed, Greece provides the only case on record in which this gap has increased beyond the first 5 years following membership.

There are three main directions for further research. One is that research is clearly needed to provide a fuller understanding of why Greece turned out to have such an exceptionally negative economic growth performance since EU accession. The returns we expect from such research activities are high, as they can certainly throw light on the current Greek situation, and hopefully even suggest ways out of it. The second direction should focus on disentangling the various aspects of the integration process, including the political economy dimension. Future analysis could focus not only on trade and financial integration but also on transparency and political support for European integration. These issues are relevant in light of the tensions that arose within the EU and especially within the Euro area as a result of the Great Recession. The third and last area for further research should focus on the specific mechanisms and channels through which EU membership seems able to support faster GDP and productivity growth rates, as these mechanisms, and their effectiveness, may well have changed over time. 


\section{References}

Abadie, A., A. Diamond, and J. Hainmueller (2010), "Synthetic Control Methods for Comparative Case Studies: Estimating the Effect of California's Tobacco Control Program," Journal of American Statistical Association 105: 493-505.

Abadie, A., A. Diamond, and J. Hainmueller (2014), "Comparative Politics and the Synthetic Control Method," American Journal of Political Science

Abadie, A., and J. Gardeazabal (2003), "The Economic Costs of Conflict: A Case Study of the Basque Country," American Economic Review 93: 113-132.

Acemoglu, D., S. Johnson, A. Kermani, J. Kwak and T. Mitton (2014), "The Value of Connections In Turbulent Times: Evidence from the United States," MIT mimeo.

Alesina, A., E. Spolaore and R. Wacziarg (2000), "Economic Integration and Political Disintegration," American Economic Review, 90(5): 1276-1296.

Allard, G. (2005), "Measuring Job Security Over Time: In Search of a Historical Indicator for EPL," Working Papers Economia wp05-17, Instituto de Empresa.

Bache, I., S. George and S. Bulmer (2011) Politics in the European Union, Oxford University Press.

Badinger, H. (2005), "Growth Effects of Economic Integration: Evidence from the EU Member States," Review of World Economics 141: 50-78.

Badinger, H. and F. Breuss (2010), "Quantitative Effects of European Post-war Economic Integration," in International Handbook on the Economics of Integration (v3), Palgrave.

Baldwin, R. (1989), “The Growth Effects of 1992,” Economic Policy 9: 247-281.

Baldwin, R. (2008), "EU Institutional Reform: Evidence on Globalization and International Cooperation,” American Economic Review 98(2): 127-132.

Baldwin, R.E. and E. Seghezza (1996), "Growth and European Integration: Towards an Empirical Assessment," CEPR Discussion Paper No. 1393.

Becker, S., Egger P. and M. von Ehrlich (2010), "Going NUTS: The Effect of EU Structural Funds on Regional Performance”, Journal of Public Economics 94(9-10): 578-590.

Bertrand, M., E. Duflo and S. Mullainathan (2004), "How Much Should We Trust Differences-In-Differences Estimates?" Quarterly Journal of Economics 119(1): 249-275.

Billmeier, A. and T. Nannicini (2013), "Assessing Economic Liberalization Episodes: A Synthetic Control Approach," Review of Economics and Statistics, 95(3): 983-1001.

Boldrin M. and F. Canova (2001), "Inequality and Convergence in Europe's Regions: Reconsidering European Regional Policies,”Economic Policy 16(32): 205-253.

Boltho, A. and B. Eichengreen (2008), "The Economic Impact of European Integration," CEPR Discussion Paper No. 6820. 
Bower, U. and A. Turrini (2010), "EU Accession: A Road to Fast-track Convergence?" Comparative Economic Studies 52: 181-205.

Brou, D. and M. Ruta (2011), "Economic Integration, Political Integration or Both?" Journal of the European Economic Association 9(6): 1143-1167.

Campos, N. and F. Coricelli (2002), "Growth in Transition: What We Know, What We Don't, and What We Should," Journal of Economic Literature XL(3): 793-836.

Campos, N. and F. Coricelli (2012), "Financial Liberalization and Its Reversals: Economic and Political Determinants," Economic Policy, 27 (71): 483-513, 2012.

Campos, N. and Y. Kinoshita (2010), "Structural Reforms, Financial Liberalization and Foreign Direct Investment," IMF Staff Papers 57(2): 326-365.

Crafts, N. and G. Toniolo (2008), "European Economic Growth, 1950-2005: An Overview," CEPR Discussion Paper No. 6863.

Crespo, J, M Silgoner, and D Ritzberger-Grünwald (2008), "Growth, Convergence and EU Membership", Applied Economics, 40: 643-656.

Dorrucci, E., S. Firop, M. Fratzscher and F. Mongelli (2004), "The Link Between Institutional and Economic Integration: Insights for Latin America from the European Experience," Open Economies Review 15: 239-260.

Eichengreen, B. (2007), The European Economy since 1945: Coordinated Capitalism and Beyond. Princeton, NJ: Princeton University Press.

Elvert, J. and W. Kaiser (2004) (Editors) European Union Enlargement: A Comparative History, London: Routledge.

Fernández-Villaverde, J., L. Garicano and T. Santos (2013), "Political Credit Cycles: The Case of the Eurozone,” NBER WP 18899.

Frankel, J. (2010), “The Estimated Trade Effects of the Euro: Why Are They Below Those from Historical Monetary Unions among Smaller Countries?" in Alesina, A. and F. Giavazzi (eds.), Europe and the Euro, Chicago: University of Chicago Press.

Friedrich, C., I. Schnabel and J. Zettelmeyer (2013), "Financial Integration and Growth: Why Is Emerging Europe Different?” Journal of International Economics 89: 522-538.

Gordon, R. (2011), "Controversies about Work, Leisure, and Welfare in Europe and the United States," in Phelps, E. and H. Sinn (eds.), Perspectives on the Performance of the Continental Economies, Cambridge: MIT Press, 343-386.

Henisz, Witold (2000). "The Institutional Environment for Economic Growth." Economics and Politics, 12(1), 1-31.

Henrekson, M., J. Torstensson and R. Torstensson (1997), "Growth Effects of European Integration," European Economic Review 41: 1537-1557. 
Henry, P. (2007), "Capital Account Liberalization: Theory, Evidence, and Speculation," Journal of Economic Literature 45: 887-893.

Imbens, G. and J. Wooldridge (2009), "Recent Developments in the Econometrics of Program Evaluation,” Journal of Economic Literature 47(1): 5-86.

Jones, C. and P. Romer (2010), "The New Kaldor Facts: Ideas, Institutions, Population, and Human Capital," American Journal of Economics: Macroeconomics 2(1): 224-224.

König, J. and R. Ohr (2012), "The European Union: A Heterogeneous Community? Implications of an Index Measuring European Integration," Universität Göttingen, mimeo.

Kutan, A. and T. Yigit (2007), "European Integration, Productivity Growth and Real Convergence," European Economic Review 51: 1370-1395.

Lane P. and G.M. Milesi-Ferretti (2007), "The External Wealth of Nations Mark II", Journal of International Economics 73(2): 223-250.

Lee, W. (2011), "Comparative Case Studies of the Effects of Inflation Targeting in Emerging Economies," Oxford Economic Papers 63(2): 375-397.

Martin, P., T. Mayer and M. Thoenig (2012), "The Geography of Conflicts and Regional Trade Agreements," American Economic Journal: Macroeconomics 4(4): 1-35.

Mitsopoulos, M. and T. Pelagidis (2012), Understanding the Crisis in Greece: From Boom to Bust, London: Palgrave MacMillan.

OECD (2011), Product Market Regulation Database, http://www.oecd.org/economy/pmr.

O’Mahony, M. and M. Timmer (2009), "Output, Input and Productivity Measures at the Industry Level: The EU KLEMS Database,” The Economic Journal 119: F374-F403.

Rivera-Batiz, L. and P. Romer (1991), "Economic Integration and Endogenous Growth," Quarterly Journal of Economics 106(2): 531-555.

Slaughter, M. (2001), "Trade Liberalization and Per Capita Income Convergence: A Difference-in-Differences Analysis," Journal of International Economics 55: 203-228.

Sapir, A (2011), "European Integration at the Crossroads: A Review Essay on the 50th Anniversary of Bela Balassa's Theory of Economic Integration", Journal of Economic Literature, 49(4): 1200-1229.

Temin, P. (2002), "The Golden Age of European Growth Reconsidered," European Review of Economic History 6: 3-22.

Vamvakidis, A. (2003), "The Convergence Experience of the Greek Economy in the EU," IMF, Washington D.C.: mimeo.

Ventura, J. (2005), "A Global View of Economic Growth", in Aghion, P. and S.N. Durlauf (eds.), Handbook of Economic Growth, North Holland, Elsevier, Vol. 1B: 1419-1497.

World Bank (2012), Golden Growth-Restoring the Lustre of the European Economic Model, Washington. 
Table 1: Economic Growth in Europe and Around the World: $1820-2008$

(Average annual compounded growth rates, GDP per capita, US\$ 1990 Geary-Khamis PPP estimates)

\begin{tabular}{lcccccccc}
\hline \hline Period & $\begin{array}{c}\text { Western } \\
\text { Europe }\end{array}$ & $\begin{array}{c}\text { Southern } \\
\text { Europe }\end{array}$ & $\begin{array}{c}\text { Eastern } \\
\text { Europe }\end{array}$ & $\begin{array}{c}\text { Former } \\
\text { Soviet } \\
\text { Union }\end{array}$ & $\begin{array}{c}\text { United } \\
\text { States }\end{array}$ & Japan & East Asia & $\begin{array}{c}\text { Latin } \\
\text { America }\end{array}$ \\
\hline $1820-1870$ & 1.0 & 0.6 & 0.6 & 0.6 & 1.3 & 0.2 & -0.1 & 0.0 \\
$1870-1913$ & 1.3 & 1.0 & 1.4 & 1.0 & 1.8 & 1.4 & 0.8 & 1.8 \\
$1913-1950$ & 0.8 & 0.4 & 0.6 & 1.7 & 1.6 & 0.9 & -0.2 & 1.4 \\
$1950-1973$ & 3.8 & 4.5 & 3.6 & 3.2 & 2.3 & 7.7 & 2.3 & 2.5 \\
$1973-1994$ & 1.7 & 1.9 & -0.2 & -1.6 & 1.7 & 2.5 & 0.3 & 0.9 \\
$1994-2008$ & 1.6 & 2.7 & 4.0 & 4.2 & 1.7 & 1.0 & 3.9 & 1.6 \\
\hline \hline
\end{tabular}

NOTES: Regional aggregates are population-weighted. Western Europe refers to Austria, Belgium, Denmark, Finland, France, West Germany, Italy, the Netherlands, Norway, Sweden, Switzerland, and the United Kingdom. Eastern Europe refers to Albania, Bulgaria, Czechoslovakia, Hungary, Poland, Romania, and Yugoslavia. Southern Europe refers to Greece, Ireland, Spain, and Turkey. After 1989, West Germany becomes Germany, and the data reflect the newly independent countries in Eastern Europe that emerge from Czechoslovakia and Yugoslavia.

Source: World Bank (2012) 


\section{Notes on Figure 1 to 3: SYNTHETIC COUNTERFACTUAL RESULTS}

There are two series plotted in each graph.

The one with a continuous line represents the actual per capita GDP levels of the country in question.

The series with a dashed line plots the synthetic counterfactual results that purport to answer the following question:

What would have been the GDP of the country in question if it had NOT become an EU member in the year it did?

The synthetic counterfactuals are presented for each country in the last four EU enlargements:

- Denmark, Ireland, and United Kingdom in the 1970s.

- Greece, Spain and Portugal in the 1980s.

- Austria, Finland and Sweden in the 1990s.

- Eastern European countries in the 2000s.

Results are presented for a donor pool of countries taken from Bower and Turrini (2010). The reported results are robust to dramatic changes in donor pool (from the whole world to selected EU neighbors); these are available from the authors upon request. 
Figure 1: Real GDP per capita in the Northern and Southern enlargements
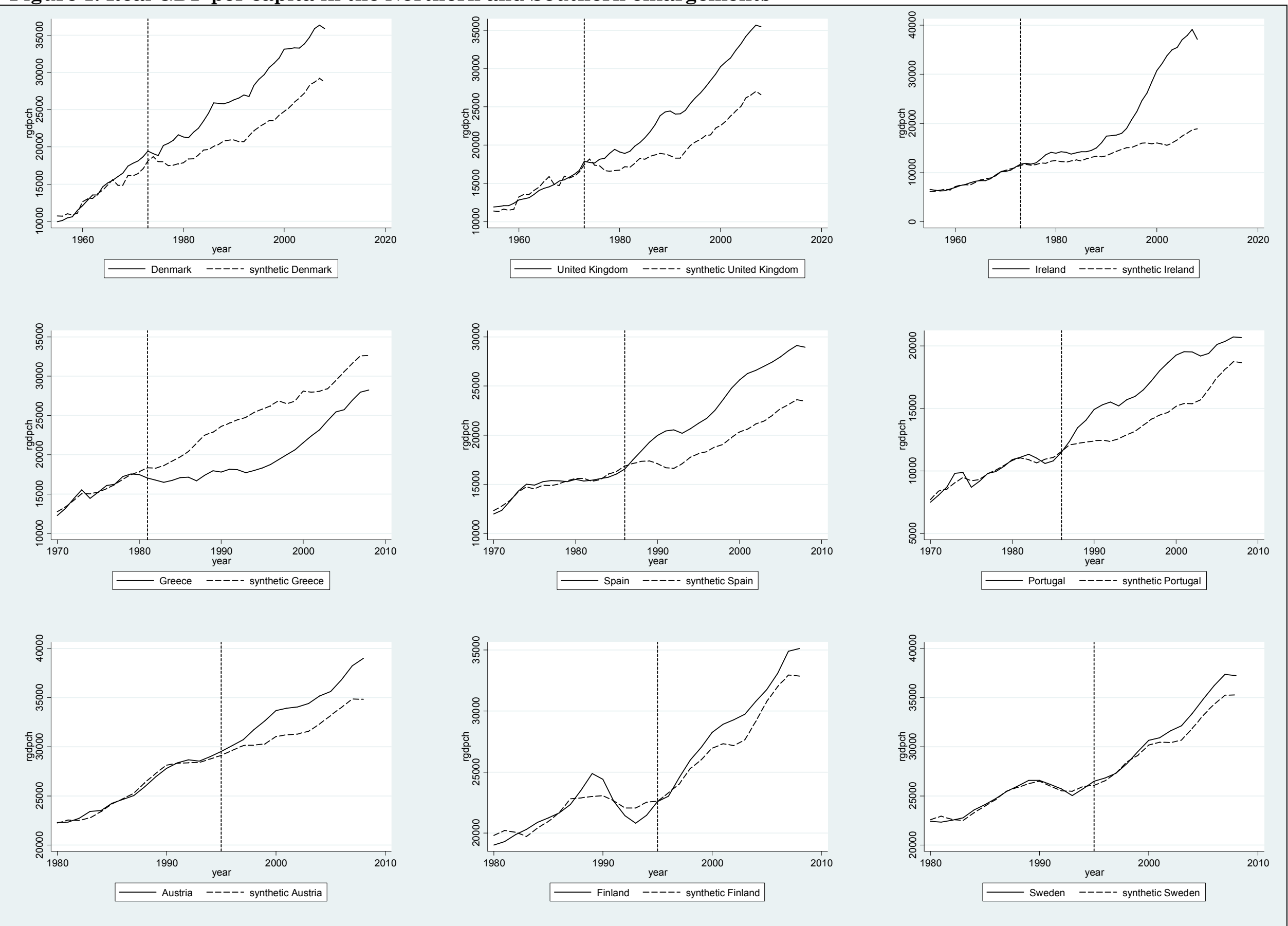
Figure 2: Real GDP per capita in the Eastern enlargement
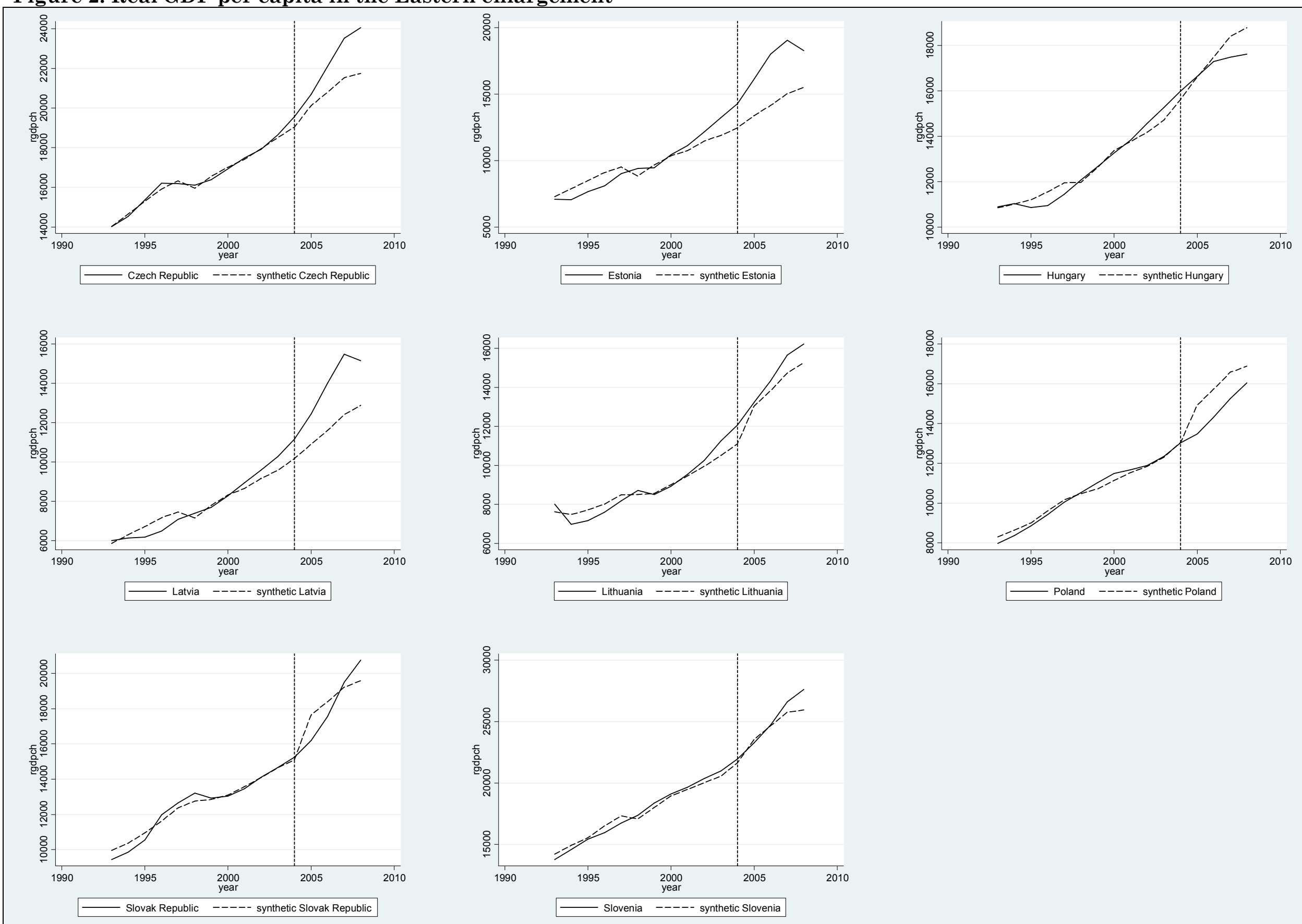
Figure 3: Anticipation effects in real GDP per capita in the Eastern enlargement

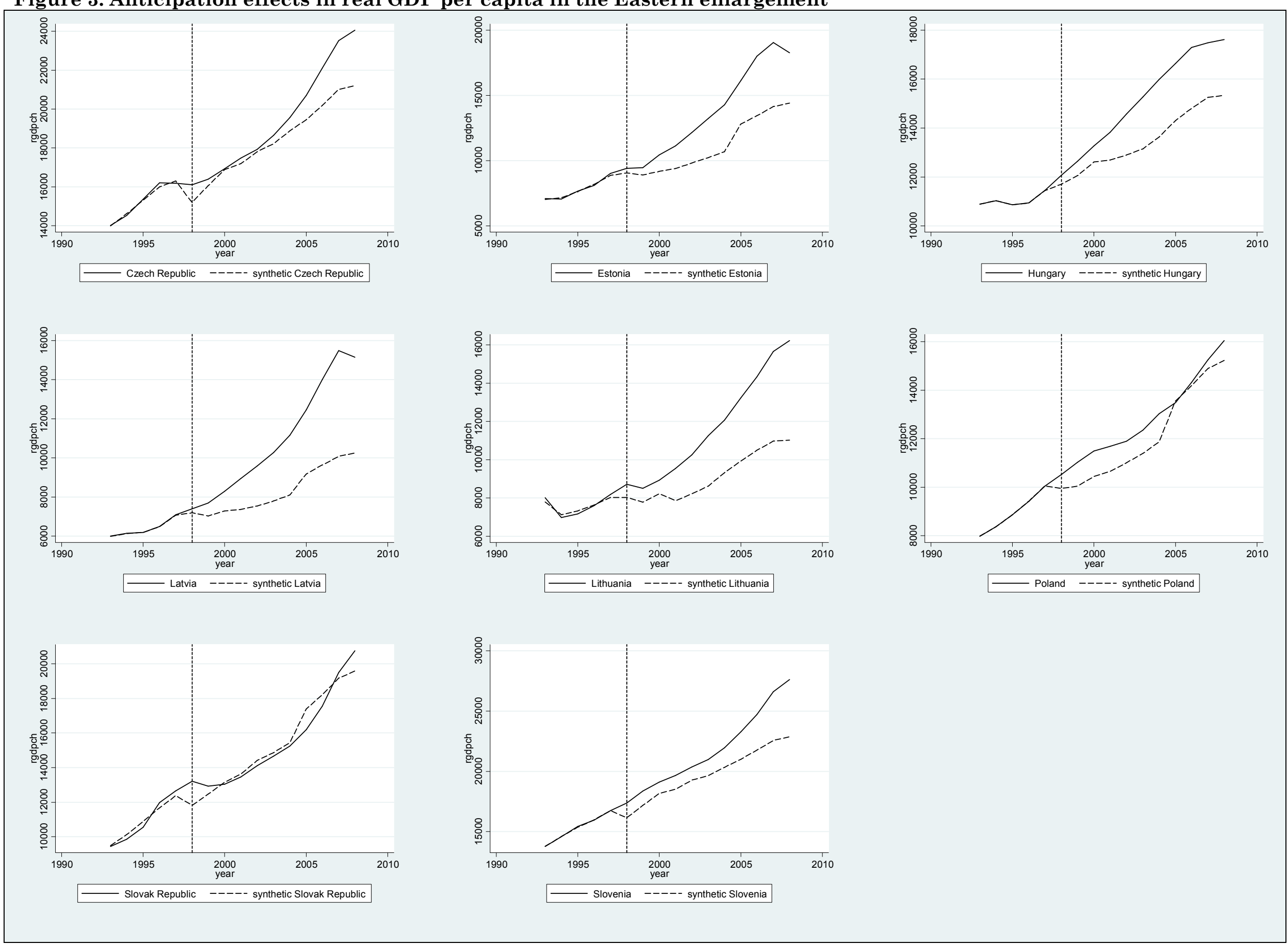


Table 2: Difference-in-differences estimates of EU membership

\begin{tabular}{|c|c|c|c|c|}
\hline & \multicolumn{2}{|c|}{ Real GDP per capita } & \multicolumn{2}{|c|}{ Labor productivity } \\
\hline & $\begin{array}{c}\text { DID estimate } \\
\text { and } \\
\text { std error }\end{array}$ & $\begin{array}{c}\text { R-square } \\
\text { and } \\
\text { Number of obs }\end{array}$ & $\begin{array}{c}\text { DID estimate } \\
\text { and } \\
\text { std error }\end{array}$ & $\begin{array}{c}\text { R-square } \\
\text { and } \\
\text { Number of obs }\end{array}$ \\
\hline Denmark & $\begin{array}{c}4810.919 \\
1393.184^{* * *}\end{array}$ & $\begin{array}{c}0.646 \\
108\end{array}$ & $\begin{array}{c}5675.021 \\
2530.716^{* *}\end{array}$ & $\begin{array}{c}0.625 \\
108\end{array}$ \\
\hline United Kingdom & $\begin{array}{c}4822.042 \\
1245.701^{* * * *}\end{array}$ & $\begin{array}{c}0.572 \\
108\end{array}$ & $\begin{array}{c}12549.3 \\
2301.925^{* * * *}\end{array}$ & $\begin{array}{c}0.622 \\
108\end{array}$ \\
\hline Ireland & $\begin{array}{c}6960.705 \\
1680.262^{* * *}\end{array}$ & $\begin{array}{c}0.483 \\
108\end{array}$ & $\begin{array}{c}11110.04 \\
3146.443^{* * * *}\end{array}$ & $\begin{array}{c}0.601 \\
108\end{array}$ \\
\hline Greece & $\begin{array}{c}-4973.705 \\
1294.363^{* * *}\end{array}$ & $\begin{array}{c}0.557 \\
78\end{array}$ & $\begin{array}{c}-7109.328 \\
2697.609^{* *}\end{array}$ & $\begin{array}{c}0.451 \\
78\end{array}$ \\
\hline Portugal & $\begin{array}{c}2636.639 \\
842.104^{* * *}\end{array}$ & $\begin{array}{c}0.700 \\
78\end{array}$ & $\begin{array}{c}3565.105 \\
1356.720^{* *}\end{array}$ & $\begin{array}{c}0.723 \\
78\end{array}$ \\
\hline Spain & $\begin{array}{c}3825.030 \\
1052.929^{* * *}\end{array}$ & $\begin{array}{c}0.656 \\
78\end{array}$ & $\begin{array}{l}2074.394 \\
1963.093\end{array}$ & $\begin{array}{c}0.676 \\
78\end{array}$ \\
\hline Austria & $\begin{array}{c}2271.567 \\
1296.521^{*}\end{array}$ & $\begin{array}{c}0.709 \\
58\end{array}$ & $\begin{array}{c}6780.129 \\
1806.187^{* * * *}\end{array}$ & $\begin{array}{c}0.731 \\
58\end{array}$ \\
\hline Sweden & $\begin{array}{c}962.307 \\
1409.562\end{array}$ & $\begin{array}{c}0.625 \\
58\end{array}$ & $\begin{array}{l}1720.407 \\
2438.039\end{array}$ & $\begin{array}{c}0.733 \\
58\end{array}$ \\
\hline Finland & $\begin{array}{l}1224.518 \\
1515.423\end{array}$ & $\begin{array}{c}0.610 \\
58\end{array}$ & $\begin{array}{l}2411.818 \\
2922.211\end{array}$ & $\begin{array}{c}0.667 \\
58\end{array}$ \\
\hline Czech Republic & $\begin{array}{l}1016.033 \\
1211.366\end{array}$ & $\begin{array}{c}0.433 \\
32\end{array}$ & $\begin{array}{l}1386.160 \\
2333.453\end{array}$ & $\begin{array}{c}0.430 \\
32\end{array}$ \\
\hline Hungary & $\begin{array}{l}1655.230 \\
744.837^{* * *}\end{array}$ & $\begin{array}{c}0.611 \\
32\end{array}$ & $\begin{array}{c}5594.308 \\
1583.882^{* * * *}\end{array}$ & $\begin{array}{c}0.684 \\
32\end{array}$ \\
\hline Poland & $\begin{array}{l}721.775 \\
960.806\end{array}$ & $\begin{array}{c}0.536 \\
32\end{array}$ & $\begin{array}{l}2462.964 \\
2102.260\end{array}$ & $\begin{array}{c}0.539 \\
32\end{array}$ \\
\hline Estonia & $\begin{array}{c}2671.465 \\
1378.483^{*}\end{array}$ & $\begin{array}{c}0.509 \\
32\end{array}$ & $\begin{array}{c}4712.617 \\
2620.998^{*}\end{array}$ & $\begin{array}{c}0.546 \\
32\end{array}$ \\
\hline Latvia & $\begin{array}{c}2626.301 \\
1014.959^{* * *}\end{array}$ & $\begin{array}{c}0.518 \\
32\end{array}$ & $\begin{array}{c}3597.256 \\
1989.464^{*}\end{array}$ & $\begin{array}{c}0.535 \\
32\end{array}$ \\
\hline Lithuania & $\begin{array}{l}2559.155 \\
987.010^{* * *}\end{array}$ & $\begin{array}{c}0.485 \\
32\end{array}$ & $\begin{array}{c}4765.042 \\
2237.021^{* *}\end{array}$ & $\begin{array}{c}0.469 \\
32\end{array}$ \\
\hline Slovak Republic & $\begin{array}{c}61.484 \\
1407.638\end{array}$ & $\begin{array}{c}0.475 \\
32\end{array}$ & $\begin{array}{l}-552.678 \\
2706.944\end{array}$ & $\begin{array}{c}0.473 \\
32\end{array}$ \\
\hline Slovenia & $\begin{array}{l}2045.426 \\
1418.580\end{array}$ & $\begin{array}{c}0.574 \\
32\end{array}$ & $\begin{array}{c}4950.848 \\
2344.542^{* *}\end{array}$ & $\begin{array}{c}0.555 \\
32\end{array}$ \\
\hline $\begin{array}{l}\text { Northern enlargement } \\
1973\end{array}$ & $\begin{array}{c}5531.222 \\
1056.741^{* * *}\end{array}$ & $\begin{array}{c}0.474 \\
324\end{array}$ & $\begin{array}{c}9778.12 \\
1759.902^{* * *}\end{array}$ & $\begin{array}{c}0.569 \\
324\end{array}$ \\
\hline $\begin{array}{l}\text { Southern enlargement } \\
1981 \& 1986\end{array}$ & $\begin{array}{l}123.6832 \\
1018.358\end{array}$ & $\begin{array}{c}0.386 \\
234\end{array}$ & $\begin{array}{c}-915.9599 \\
2758.41\end{array}$ & $\begin{array}{c}0.247 \\
234\end{array}$ \\
\hline $\begin{array}{l}\text { Southern enlargement } \\
1986\end{array}$ & $\begin{array}{c}3230.834 \\
1089.213^{* * *}\end{array}$ & $\begin{array}{c}0.467 \\
156\end{array}$ & $\begin{array}{c}2819.75 \\
3205.809\end{array}$ & $\begin{array}{c}0.245 \\
156\end{array}$ \\
\hline $\begin{array}{l}\text { Northern enlargement } \\
1995\end{array}$ & $\begin{array}{l}1486.131 \\
966.6537\end{array}$ & $\begin{array}{c}0.552 \\
174\end{array}$ & $\begin{array}{c}3637.451 \\
2056.951^{*}\end{array}$ & $\begin{array}{c}0.490 \\
174\end{array}$ \\
\hline $\begin{array}{l}\text { Eastern enlargement } \\
\text { (1998-anticipation effect) }\end{array}$ & $\begin{array}{c}1669.609 \\
992.2974^{*}\end{array}$ & $\begin{array}{c}0.186 \\
256\end{array}$ & $\begin{array}{c}3364.564 \\
2043.261^{*}\end{array}$ & $\begin{array}{c}0.189 \\
256\end{array}$ \\
\hline
\end{tabular}

NOTES: These results assess the statistical significance of the differences between the average difference pre-treatment (between the actual country and its synthetic) and the average difference post-treatment (between the actual country and its synthetic) estimated by the synthetic counterfactuals in Figures 1, 3 (and A.1 and A.3 in Appendix). Results are presented for each country and then for each enlargement and for GDP per capita and labor productivity series. Robust standard errors are reported. Inference: $* * *$ $\mathrm{p}<0.01 ; * * \mathrm{p}<0.05 ;{ }^{*} \mathrm{p}<0.1$ 
Table 3. Difference between country's Actual and Synthetic Per Capita GDP paths

\begin{tabular}{|c|c|c|c|c|c|c|}
\hline & \multicolumn{3}{|c|}{$\begin{array}{l}\text { DIFFERENCE (\%) in post-treatment } \\
\text { average GDP pc LEVEL } \\
\text { between ACTUAL and SYNTHETIC }\end{array}$} & \multicolumn{3}{|c|}{$\begin{array}{c}\text { DIFFERENCE (pp) in post-treatment } \\
\text { compounded annual GDP pc GROWTH RATE } \\
\text { between ACTUAL and SYNTHETIC }\end{array}$} \\
\hline & $\begin{array}{l}\text { All post- } \\
\text { treatment }\end{array}$ & $\begin{array}{c}10 \text { years after } \\
\text { treatment }\end{array}$ & $\begin{array}{l}5 \text { years after } \\
\text { treatment }\end{array}$ & $\begin{array}{l}\text { All post- } \\
\text { treatment }\end{array}$ & $\begin{array}{c}10 \text { years after } \\
\text { treatment }\end{array}$ & $\begin{array}{c}5 \text { years after } \\
\text { treatment }\end{array}$ \\
\hline Denmark & 23.863 & 14.298 & 10.292 & 0.441 & 1.038 & 2.038 \\
\hline United Kingdom & 23.694 & 8.586 & 4.824 & 0.763 & 0.951 & 2.118 \\
\hline Ireland & 48.900 & 9.395 & 5.242 & 1.915 & 0.883 & 2.348 \\
\hline Greece & -19.758 & -17.336 & -11.591 & -0.271 & -2.111 & -2.037 \\
\hline Portugal & 18.351 & 16.537 & 11.733 & 0.498 & 1.988 & 4.355 \\
\hline Spain & 19.806 & 13.662 & 9.348 & 1.054 & 1.910 & 4.463 \\
\hline Austria & 7.208 & 6.364 & 4.467 & 0.778 & 0.589 & 1.393 \\
\hline Finland & 4.365 & 4.017 & 2.185 & 0.541 & 0.335 & 1.012 \\
\hline Sweden & 3.174 & 2.353 & 0.823 & 0.299 & 0.329 & -0.016 \\
\hline Czech Republic & 5.615 & 5.615 & 2.110 & 0.711 & 0.711 & -0.717 \\
\hline Estonia & 24.153 & 24.153 & 16.342 & 2.110 & 2.110 & 4.591 \\
\hline Hungary & 12.299 & 12.299 & 8.734 & 1.108 & 1.108 & 2.452 \\
\hline Latvia & 31.692 & 31.692 & 18.016 & 3.839 & 3.839 & 5.209 \\
\hline Lithuania & 28.082 & 28.082 & 17.352 & 3.191 & 3.191 & 3.825 \\
\hline Poland & 5.930 & 5.930 & 8.670 & -0.045 & -0.045 & 0.518 \\
\hline Slovak Republic & 0.302 & 0.302 & 1.315 & -0.563 & -0.563 & -2.597 \\
\hline Slovenia & 10.350 & 10.350 & 6.327 & 1.206 & 1.206 & -0.141 \\
\hline $\begin{array}{l}\text { Northern enlargement } \\
1973\end{array}$ & 32.152 & 10.760 & 6.786 & 1.040 & 0.957 & 2.168 \\
\hline $\begin{array}{l}\text { Southern enlargement } \\
1981 \& 1986\end{array}$ & 6.133 & 4.288 & 3.164 & 0.427 & 0.596 & 2.260 \\
\hline $\begin{array}{l}\text { Southern enlargement } \\
1986\end{array}$ & 19.078 & 15.099 & 10.541 & 0.776 & 1.949 & 4.409 \\
\hline $\begin{array}{l}\text { Northern enlargement } \\
1995\end{array}$ & 4.915 & 4.244 & 2.491 & 0.540 & 0.418 & 0.796 \\
\hline $\begin{array}{l}\text { Eastern enlargement } \\
1998 \text { (anticipation) }\end{array}$ & 14.803 & 14.803 & 9.858 & 1.445 & 1.445 & 1.642 \\
\hline
\end{tabular}


Table 4. Determinants of the growth dividends from EU membership

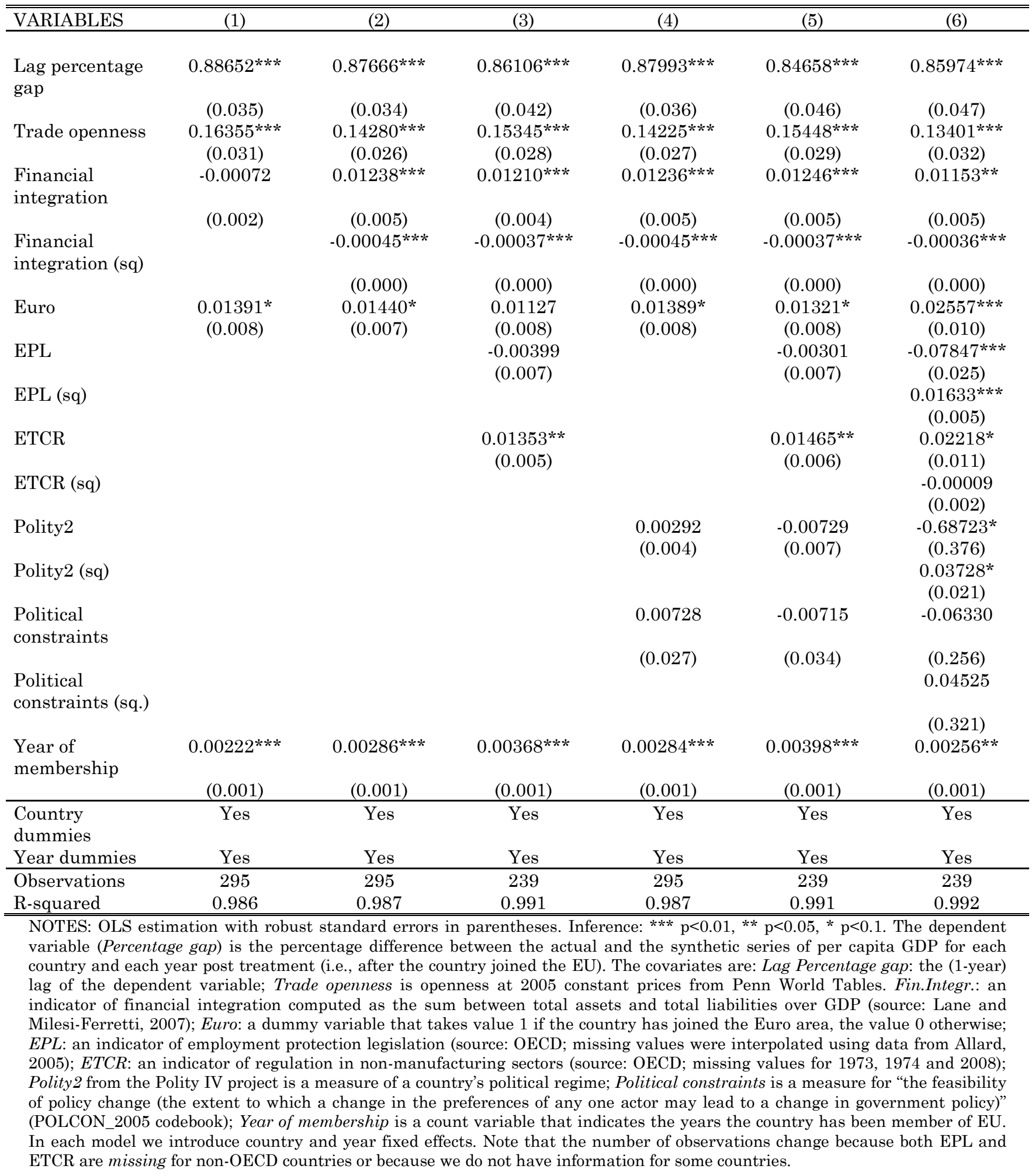

